\title{
Modern Lines of Education in the Field of Culture and Art in the Context of Globalization
}

\author{
Igor Hriptulov \\ Smolensk State Institute of Arts \\ Smolensk, Russia \\ E-mail: iuliy_67@mail.ru
}

\begin{abstract}
In this article, the analysis of the tendencies of development for profile education in the sphere of culture and art in the Russian Federation and assessment of their influence on the state cultural policy is carried out. Relevance of the conducted research consists in assessment of a role of profile education in the sphere of culture and art within realization of the state cultural policy for modern Russian society. Today, gradually the understanding that Russia needs development as to one of the leading states and the equal member of the world community, but not a raw appendage which is possible only when determining by a national priority of development of the country - cultures comes.
\end{abstract}

Keywords-culture; the state; cultural policy; education in the sphere of culture and art

\section{INTRODUCTION}

In recent years, the highest education faced new challenges: growth of cost of education, use of new technologies, interdependence of university education and prospects of employment. In modern conditions, a problem of education has a key value and influences "goal achievement of sustainable development of the modern world" (UN). The main potential of education in the sphere of culture and art is a number of the international documents: "The Seoul agenda" of UNESCO, the Concept of development of education in the sphere of culture and art of the states of the CIS, the Resolution of a meeting of the Business APEC summit "Education as the key to success".

The defining education role in the sphere of culture and art in the globalized world is defined by need to opposition to anti-humanity, phenomena of mass art, platitude and cynicism in culture. At the same time, Russian education in the sphere of culture and art has humanistic spiritual ideals of the truth, good, beauty and love and can become the spiritualizing rule of social life of people, and Russian education in the sphere of culture and art doesn't demand additional confirmation anywhere in the world.

The modern world welfare situation is characterized by the beginning of a new stage of cultural process which is expressed in need not only developments of the unified educational standards and the general requirements to competences of experts, but also expansions of a range of professions of a welfare profile.
Relevance of this research is caused by the fact that modern problems of education in the field of culture and art are caused by a number of the factors connected with transformation of public life and modern policy of Russia in which laws of cultural practice, and art is even more often shown. There are tasks of harmonization regarding the rationality and emotionality that began in socio-cultural area of public life, implementation of a trans-humanistic approach in social practice where cultural regulations serve as a measure of human development and society started.

\section{PURPOSES AND METHODS}

The purpose of work is for the generalization of theoretical bases and the systematization of methods preservation of cultural originality and specific features of an education system in Russia, in particular, a continuity and multi-gradualness of art education and the centralized management of educational institutions in the field of culture and art.

Dynamics of historical development of education in the field of culture and art is defined by processes of preservation of traditions, introduction of innovations. Keeping a demand in Russia today, these phenomena change the configuration, get various conceptual frameworks. Process of integration of Russia in the world, with her special geopolitical, ethnic and religious position, creates other system of measurement of transformations and staticizes a perspective of culture of regions.

The purpose of the publication is the analysis of the available scientific literature and results of a research of tendencies of development of profile education in the sphere of culture and art in the Russian Federation and their influence on the state cultural policy. The theoretical importance of this work is caused by novelty of subject and lack of analogs of the conducted researches. The empirical base used in this scientific work can be used as historiographic material in case of further profound development of a perspective of a question. In work, the Ministries of Education of the Russian Federation, the Ministry of Culture of the Russian Federation, materials of collective monographs of the author, and also reports and data of empirical researches of the Russian and foreign scientists were used. 


\section{RESULTS AND DISCUSSION}

\section{A. Education in the Sphere of Culture and Art in the Conditions of Globalization}

Education - this is one of the best and fastest methods of human entry into the sphere of science and culture. It is in the process of education is the formation of cultural identity values. Today, there is the problem of preserving cultural identity and specificity of the educational system in Russia, in particular, continuity and multi-arts education. Educational institutions centralize management.

Features of professional education in the field of culture and art are shown:

- when receiving students in higher and secondary specialized educational institutions, where the results of the unified state exam is not a determining element. We should be entering certain creative abilities, to identify who provided the creative direction of the test.

- in the peculiarities of the profession and the methods of its realization, as the development of educational programs and how connected with the study of scientific disciplines, and with the development of creative abilities. [3]

Considering features of the higher education in the field of culture and art at the beginning of the twenty first century, it is necessary to emphasize that importance of this educational structure is determined by the legislation of the Russian Federation. So, according to the Federal law "About Culture and Preserving Cultural Heritage: the culture is recognized as a spiritual and moral basis of development of modern society Russia". The embodiment of this idea it is possible in case of existence of system of the professional training directed to preserving valuable orientations of culture and art, high moral and esthetic ideals, regulations and cultural traditions. Higher vocational education is an effective mechanism for cultural translation. [2] One way of improvement of activity for this mechanism is the emphasis on the ideas of moral education of the person, major for Russian education, which has to have a wide range of knowledge, being the highly qualified specialist capable to defend the own principles of life, trying to reach not only the material, but also spiritual, vital and career purposes.

However, the carried-out analysis of scientific works gives the grounds to claim that so far enough complete research in which the education phenomenon in the field of culture and art was considered in the context of globalization weren't conducted. At the same time, the happening regional socio-cultural transformations generate the whole amount of contradictions in this sphere:

- between the needs of innovative, creative development for information society and narrow professionalizing of education in the field of culture and art;

- between the need to preserve the cultural space and a single national-cultural autonomy;
- between the processes of globalization and regionalization objectively arising from different levels of economic, political, social and spiritual spheres of public life;

- between functioning of Russian education in market conditions and loss of exclusive state functions in this area;

- between potential opportunities of education in the sphere of culture and art and its real state in the Russian regions [4].

In 2015, formation of branch of culture has been presented by 5338 educational institutions. From them, 59 higher education institutions (including under the authority of the Ministry of Culture of the Russian Federation - 48), 275 professional educational institutions (from which under the authority of the Ministry of Culture of the Russian Federation - 10 institutions), and 5108 children's schools of arts (further - CShA), which generally are under authority of municipalities.

In educational institutions in 2015 subordinated to the Ministry of Culture of the Russian Federation (10 schools and 48 higher education institutions) studied 66248 people, 10329 pedagogical workers worked and 118 educational programs in the field of arts and culture were implemented.

The priorities of the Russian Ministry of Culture of the educational policy in 2015 were as follows:

- improvement of the quality of the three-tier system of art education and the provision of cultural and educational institutions with professional staff. Measures taken to ensure the employment of graduates of art schools budget form of training will: employ $77 \%$ of the students, while in 2014, in 2015 $76 \%$, and in $2011-53 \%$.

- the development of international relations in order to increase Russia's influence in the international arena, the positioning of the domestic arts education in the world educational space, the formation of the future professional and political elite of other countries. In December 2015, Beijing within the XX regular meeting of the heads of governments of Russia and China signed a memorandum on cooperation in education and science in the field of culture between the Ministry of Culture of Russia and the Ministry of Education of China. An international association of creative high schools (from the Russian side in the association includes 18 universities, led by Moscow and the St. Petersburg Institute of Culture).

- increase of the salaries of teachers and the development of material and technical base of educational institutions. To this end, educational institutions has continued to internal optimization: increased teaching load, optimize the number of fulltime staff, as well as the mode of operation, reduce the number of administrative staff, making the transition to outsourcing non-core services. In the conditions of reforming and modernization of the 
national system of art education, to preserve valuable artistic traditions that have evolved and developed by generations of experts in the field of culture and art for two centuries. It is impossible in an era of change to break the experience and the Russian system of professional art education "school - college - high school".

\section{B. The Specifics of the Development of Regional Systems of Education in the Field of Culture and Art}

A special education system in the region in the field of culture and art in the context of globalization picked their cultural "location", which is associated with the peculiarities of the cultural traditions of a region, state historical and cultural memory, resources, information dynamics and degree of participation of Russian regions in intercultural dialogue "Fig. 1". There are three models of regional education in the field of culture and art - networking, cooperating and synthesizing.

\begin{tabular}{|c|c|c|c|}
\hline \multicolumn{2}{|c|}{$\begin{array}{l}\text { Improvement of system of financing and management in the sphere of culture } \\
\text { Development of science, resolution of the international research } \\
\text { programs }\end{array}$} & \multicolumn{2}{c|}{ Development of modern cultural clusters } \\
\hline
\end{tabular}

Fig. 1. Backbone factors of uniform educational space in the sphere of culture and art.

According to the dynamics of passage, regions globalization processes can be identified as the "locomotiveregions"; "Reference areas"; "Growth pole regions"; "Depressed regions"; "Regions of special attention." The uneven development of regions and education systems make it possible to use culture as a strategic resource to align territories. The ongoing regionalization of culture determines the state of education in this area and reflects the specific interactions of the "center - regions" and determines the choice of one's own culture and the development strategy of education development programs

Education systems in the field of culture and art in the regions of Russia occupies in the educational space of the country a special place, and often outside the legal field. Now, there is no full-length at the federal level and deeply balanced approach to the legal regulation of this process. This increases the need to adjust existing legislation in the management of vocational education in the arts and culture [6].

Relying on cultural wealth, these educational systems remain self-sufficient, in a certain measure independent of a political situation and show probability of changes within logic and laws of self-development. Unevenness of development of regions and educational systems gives the chance to use culture as a strategic resource of development for equalization of the territories. The ongoing regionalization of cultural influences the state of education in this area, indicating the existence of the effect of the autonomy of education systems [3].

Regionalization of education in the field of culture and art reflects the dialectic interaction "center - regions", defining the choice of one's own culture and its own development strategy for education development program in accordance with the socio-economic, geographic, cultural, spiritual, ethno-demographic and other conditions.
Despite the overall, system-situation for all regions of the country, given by the GEF IN, with methods of implementation are different in each region based on local circumstances and priorities. Suitable solutions in the field of education for one region may not be acceptable in another because of the existing differences in cultural policy. In the context of the realities of globalization, the main trend of education in the sphere of culture and art is the diversification of its functions.

In the process of globalization, it emphasizes the special mission of education in the field of culture and art, the inner expression of which is reflected in the harmonization of relations in Russian society, creating readiness for intercultural dialogue on the basis of positive Russian traditions. The professional competence of a specialist in the field of culture and art is defined as the overall development of activity-related and personal characteristics in the society, making it possible to qualitatively carry out professional activities on the human involvement in the world of culture, the implementation of culture-creative potential in life [8].

\section{CONCLUSIONS AND RECOMMENDATIONS}

The multilevelness of the existing system of professional education provides development of its continuity, turning into "education through all life". This principle creates conditions for implementation of various educational programs taking into account age, personal qualities, level of the available education, demand in the labor market. Step training gives the chance to gain professional knowledge in the form of separate modules of information that gives the chance of the personality independently to build the educational career [7].

Variability and flexibility of education programs in the field of culture and art provide a wide range of knowledge, professions, specialties, specializations and gives the chance 
of self-checking personality over time and the speed of development of knowledge. Universality of educational system develops regional network of educational institutions, forming unique cultural educational space to give to the population equal opportunities in vocational training, in retraining and professional development

\section{REFERENCES}

[1] Agapov, NG Paradigmal orientation and model of modern education (system analysis in the context of the philosophy of culture): monograph. / NG Agapov. Ryazan: Ryazan. state. untim. C. Esenina, 2008. - 360 p.

[2] Baydenko, VI Problems of modernization of higher education in Russia: monograph. Text. /IN AND. Baydenko. -M .: MAKS Press, 2010.-290p

[3] Irhen, II Russian education in the field of culture and art: Global and regional dimensions: dis. ... Doctor of cultural science: 24.00.01 / Irhen Irina I.; [A protection Place: Mosk. state. Univ of Culture and Arts] .- Moscow, 2012. - 435 p.

[4] Luzan VS The role of specialized education in the field of arts and culture in the implementation of the state cultural policy // Scientific and methodical electronic journal "Concept". - 2016. - V. 15. - P. 1011-1015.

[5] Romanova Y.A. Optimization of selection and adaptation of professional staff in the organization. - Bulletin of Moscow University. Witte. Series 1: Economics and Management. 2015. №1 (12). P.70-79

[6] Romanov Y.A., Egorenko A.S. "Effective contract" as an innovative tool in the field of higher education of the Russian Federation. // Collected articles on materials of the international scientific-practical conference. - 2015. P.167-170.

[7] Yaroshenko, NN Valuable content of education in the field of culture and arts: the context of intercultural communication text. / $\mathrm{NN}$ Yaroshenko // Bulletin of Moscow State University of Culture and Arts. 2011. - №5. - P. 27-34.

[8] Appadurai A. Modernity at Large. Cultural Dimensions of Globalization. Minneapolis. London, 1998. - 224 p.

[9] Hardy, Tom. Art education in postmodern world Text. / T. Hardy. Briston: Intellect Books, 2006. - 166 p. 